\title{
Spectra of ICR-resonated species in sheet plasma
}

\author{
シートプラズマを用いたICR加熱による共鳴イオンのスペクトル
}

Yuko HIROTA

Department of Nuclear, School of Engineering,

Tetuya MIKURINO and Kenzou NANRI

Department of Phisics, School of Science,

Ei ji YABE and Kazutaka KAWAMURA and Kazuo TAKAYAMA

Institute of Research and Development,

Tokai University, 1117Kitakaname, Hiratsuka, Kanagawa, 259-12 Japan

TEL:81-58-1211(EX.5305), FAX:81-58-1203

( Accepted for publication 8 November 1996 )

The fundamental study on the isotope separation in the sheet plasma by using ion cycloton resonance has been carried out. The newly designed orifice is used to reduce the electron density in sheet plasma, the results, however, indicate only the separation between the different species

Key words : sheet plasma, orifice, ICR

\section{INTRODUCTION}

シートプラズマとイオンサイクトロン共鳴法 (ICR) を用いての同位体分離の基礎的実験を行っ た。シートプラズマは、プラズマの厚さがイオ ンのラーマー半径のおよそ 2 倍、 $2 \mathrm{~mm}$ 程度まで 薄くした板状のプラズマである。電子とイオン のラーマー半径の違いから中心に電子、外側に イオンが多く存在し、電位勾配を持つことが特 徵である。このようなシートプラズマに R F 電 場を印加し、ICRによりイオンを選択的に検出 させようとする試みは、この電位勾配のためこ れまで成功しなかうた。

そして今回の実験では、ダブルスリット型オ リフィスシートを用い中心部の電子を取り除き、 プラズマの電子密度を低くすることで ICR 加熱 の効果を引き上げる試みを行った。

\section{EXPERIMENTAL}

A. Production of sheet plasma

r f 電場プラズマ源には, TP-D ( Test Plasma Produced by DC Discharge) 型プラズマ源（Fig. 1 参照）を用いた。直流放電により作られたプラ ズマは、陽極にあけた縦 $2 \mathrm{~mm}$ 、横 $20 \mathrm{~mm}$ の
スリットから差動排気によって、シート上に生 成されて実験領域に噴出する。

実験領域ではシートプラズマを挟むように配 置した平行平板電極 (幅 $10 \mathrm{~cm}$ 、長さ $20 \mathrm{~cm}$ ) により r f 電場を印加して ICR を観測した。

$\mathrm{r} \mathrm{f}$ 電源は周波数可変範囲 $20 \mathrm{kHz}$ から $220 \mathrm{kHz}$ 最大電圧 $\mathrm{V} \mathrm{p}-\mathrm{p}=40 \mathrm{~V}$ を用いた。 ICR 起こしたイオンは次第にラーマー半径 が大きくなり、 $\mathrm{r}$ 電極に衝突する。したがっ て平行平板電極とアース間に接続した抵抗を流 れる電流を測定することにより共鳴イオンを検 出する。

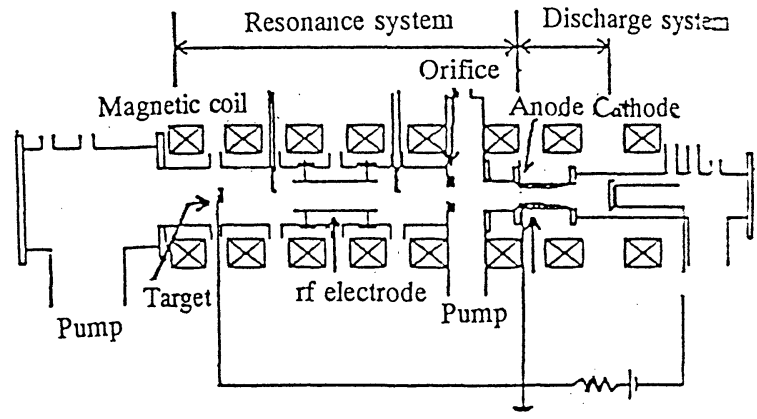

FIG.1. Experimental apparatus. 
B. Orifice with double slits

オリフィスとはシートプラズマの電子密度を 下げる目的で考案された。2つのスリットが付 いた金属板と絶縁板とで構成され、陽極の後ろ 側に設置する。（Fig. 2 参照）シートプラズマ の電子は中心部に分布している為、シートプラ ズマがオリフィスを通過する際に、イオンは 2 つのスリットから通過するが、電子はスリット の間の金属板によって取り去られる仕組みとな っている。

オリフィスを設置し、プラズマの密度を低く することで ICR 加熱の効果を引き上げている。

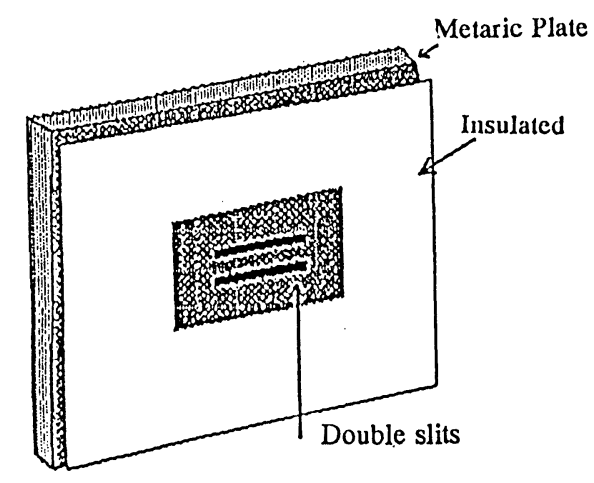

FIG.2.The constraction of the orifice with double slits.

\section{C.Measuring method}

本実験では放電ガスとして、 $\mathrm{Ar}$ を用いた。 放電領域のガス圧は〜 $10^{-3}$ [Torr]、磁場は 199 [G]で一定とし、実験領域のガス圧は〜 $10^{-7}$ [Torr]、磁場の強さは中心軸上において、

$13886[\mathrm{kG}]$ から $2464[\mathrm{kG}]$ まで変化させた。 $\mathrm{R} \mathrm{F}$ 電場の電圧は $40[\mathrm{~V}]$ 、周波数は 20 $[\mathrm{kHz}]$ から $220[\mathrm{kHz}]$ まで変化させた。

イオンの質量数によって共鳴周波数が異なる ことを利用し、実験領域の磁場を変化させたと きの共鳴周波数の推移によりイオン種を特定す る。

\section{RESULT}

期待されていた同位体分離は検出されず、イ オン種の分離にとどまっている。

質量の軽いものほど低周波よりに検出される ことを考え、理論值との比較でFig.3 を見ると、 検出されたイオンは低周波より順次に、Ar、N、 $\mathrm{O} 、 \mathrm{H}_{2} \mathrm{O}$ であることがわかる。

それぞれの值は理論值よりも高周波よりにお よそ $10 \mathrm{k} \mathrm{H} \mathrm{z}$ シフトしている。これはシート プラズマ内での電場による影響を受けているた めに理論值よりも大きく出ると予想される。

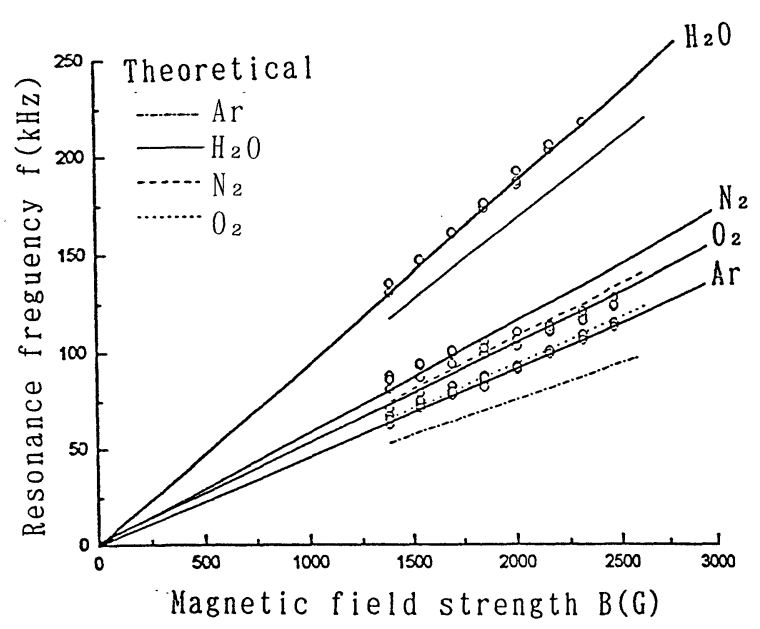

FIG.3. Relation between the resonance frequency and the magnetic field strength at the resonance peak.

\section{REFERENCE}

1 K.Nanri,M.Matumura, and M.Homma,N.Kinoshita E.Yabe,K.Kawamura, and K.Takayama; IX International Conference on Ion Implantation Technology

'96 SAS Intelligent Symposium 